\title{
How the 'natives' and the 'hybrids' are transforming South African journalism
}

\author{
$\underline{\text { Mpumelelo Mkhabela }}$
}

Addressing the American Society of Newspapers Editors in April 2005, Rupert Murdoch, media mogul and owner of News Corporation, made several profound statements which were reported in The Independent (2005-04).

Firstly he said: 'Like many of you, I am a digital immigrant. I wasn't weaned on the web, nor coddled on a computer. I grew up in a highly centralised world where news and information were tightly controlled by few editors, who deemed to tell us what we could and should know.'

Secondly, he stated: 'The peculiar challenge, then, is for us digital immigrants - many of whom are in positions to determine how news is assembled and disseminated - to apply a digital mindset to new set of challenges.'

Thirdly, Murdoch cited a Carnegie Report, which stated: 'There is a dramatic revolution taking place in the news business today, and it's not about TV anchor changes, scandals at newspapers or embedded reporters. The future is being altered by the technology-savvy young people [natives] no longer wedded to traditional news outlets or even accessing news in traditional ways.'

South Africa's media entrepreneur, Koos Bekker, the MD of Naspers, recently stated that some of Media24's publications had no growth prospects in print form. They could only grow on-line. The launch of The Times, by media group Avusa, was yet another acknowledgement, if not an illustration, that readers/consumers no longer want to be passive readers of content. The interactive nature of The Times ensures that they can write back (The Times blogosphere).

My view is that in addition to the 'digital immigrants' and the 'digital natives', we have the 'digital hybrids'. I think the largest consumers of news media are hybrids, just as the producers (the journalists) are the 'hybrid types'.

Several points could be made out of Murdoch’s formulation and observations:

- Newsrooms are undergoing 'creative destruction', a concept introduced by economist Joseph Schumpeter. According to this process: 'The fundamental impulse that sets and keeps the capitalist engine in motion comes from the new consumers, goods, the new methods of production or transportation, the new markets, the new forms of industrial organization that capitalist enterprise creates... The opening up of new markets, foreign or domestic, and the organizational development from the craft shop and factory to such concerns as U.S. Steel illustrate the same process of industrial mutation- ...that incessantly revolutionises the economic structure from within, incessantly destroying the old one, incessantly creating a new one. This process of Creative Destruction is the essential fact about capitalism' (Schumpeter, 1975). 
- With regard to the media, our newsrooms, or 'the forms of industrial organisation', and the journalism profession or the 'methods of production', are being creatively destroyed because of the emergence of the 'new consumers' - the 'digital natives' and 'hybrids'.

- At a more practical level, how does it affect journalists? Let's look at the methods of producing news - and here I am not referring to the creative destruction that took place when the old manual printing presses were replaced by the new computerised machines. I am referring to the changing ways of news gathering and publishing. Today you can do video conferencing, send email inquiries and conduct an Internet search from a myriad of search engines - both globally and locally.

For example, when I first arrived in the newsroom in 1999, there were journalists who could not use the Internet and did not know how to send emails. They were the immigrants. Today, you could hardly imagine such a scenario. In fact, in the case of today's graduates, you will be hard put to find someone in the newsroom who battles to send an email. We are also exposed to vast amounts of information readily available on the Internet for research purposes. But the information on the Internet is available to anyone who cares to conduct a search. Some of it is not necessarily reliable, which means it is not a replacement for researching stories. Of course, we take all of these for granted nowadays.

- Part of creative destruction has entailed the extension of the print newspaper to the web. I'm not aware of a single newspaper in South Africa - with the exception of regional newspapers perhaps - which has not developed web content. In addition, the newspapers have moved away from simply cutting and pasting on the web what they had printed on paper. Websites are updated continuously, with implications for journalists.

For example, when I started reporting on Parliament in 2001, whenever there were newsworthy statements from parliamentary sittings or parliamentary committees there was nothing I could immediately do about those, except to stress about the so-called 'Sunday angle'. Today, whenever something happens that is newsy, I run immediately either to blog it on The Times blogosphere or to write a short news story and instantly publish it on The Times website.

- There are certain implications in this for me. Employed as a Sunday newspaper journalist, I sometimes work as though I was a news wire reporter. It is fun. But it can also be taxing.

For example, in the past, when the central bank governor Tito Mboweni came to address Parliament's portfolio committee on finance on a Tuesday, I could sit and relax and enjoy listening to the economic jargon. Afterwards I would talk to MPs and other financial experts, with a view to exploring a 'Sunday angle' or writing a column for the Sunday edition. However, at a later stage, as soon as Mboweni had said something that could potentially move the markets, I would, if I wished, join my colleagues from Bloomberg, AP and SAPA when they ran to file that bit of information, which would be destined for stock exchanges and other business consumers. Today, I can neither take my time to chew the economics figures nor do I run to the office. Instead, I am able to bring my laptop computer to the meeting and file directly to the website while Mboweni speaks. And as he speaks, I can already get a reaction from the readers!

Another example: when we were covering the ANC conference in Polokwane in December, just hours after former President Thabo Mbeki lost the elections to Zuma, Justice Malala, The Times enterprising columnist, wrote an interesting blog. It was more of a live coverage 
of what he was observing: the reaction of SABC staffers to the news. Malala wrote the following as an intro for The Times blog, 'Politically Correct': 'I am sitting inside the SABC's massive marquee and it looks and feels like a beloved uncle has died. SABC

bigwigs are walking around looking glum, as if they have lost an election. And maybe they have' (blogs.thetimes, 2002-12). In few minutes, there were some responses to the blog. There were people who were following our 'blogging coverage' of the conference as if they were watching live TV. This is a graphic illustration that the 'digital native' loves his or her PC, especially considering that the blog was filed in the evening.

- There are certain implications if you have to instantly file complicated data (excluding the Malala blog referred to above). Not only are you expected to understand complex economic data or complex legislation in a short space of time, but you should also be able to report on it in simple language - and quickly. An important draw card for any website worth its salt, is to consistently prove to readers that you are on the ball, and on time.

For example, when Mbeki was due to be fired by the ANC on a Friday, we were all awaiting the final decision of the National Executive Committee (NEC), which was locked in a meeting for most part of the day. The decision was taken sometime around midday. One of our reporters got the information, and we filed it instantly on the website as breaking news before the ANC could announce the following day. There was a risk that because there was little time to verify the information with many sources, you could easily get it wrong. But then during that short space of time, several sources confirmed it.

- Once again there are implications for this: you need to have the ability to cross-check your facts quickly before you publish it on the web. One can call this 'just-in-time-journalism'. Those who have studied international business would know what happened when Fordism the process of manufacturing vehicles using huge production and assembly lines - changed when Toyota invented that 'just-in-time-production', where the assembly lines were no longer necessary. Everything was now done instantly in a centrally controlled nerve centre. I think we have arrived in that era: we have become 'just-in-time-producers' of news.

- The other aspect of the creative destruction of journalism is the multi-media packaging. Because of the demands placed on journalism by the 'digital natives' and their 'hybrid cousins', it is no longer enough to file a story in the written word on the web. It has to be accompanied by a multi-media video, file pictures and possibly podcasts etc.

- The implication is that a 'just-in-time-reporter' has to understand the modern digital media in all its facets. Not so long ago, it was enough for a reporter to be accompanied by a photographer when covering an event or conducting an interview. Today, in addition to a photographer you also need a multi-media reporter. Alternatively, as you conduct your interview, you would have to carry multi-media equipment.

It is quite evident that journalism will never be the same again. I may be young, but I can claim that in my limited experience as a journalist, a revolution of news media has happened right before my eyes and I have embraced it. The massive creative destruction that is taking place in newsrooms is no less significant than the invention of TV. Thanks to technology and its offspring - the natives and hybrids. 
doi: $10.5789 / 2-2-27$

\section{References}

Schumpeter, J. 1975. Socialism, Capitalism and Democracy. New York: Harper.

The Independent. http://www.independent.co.uk/news/murdoch-my-media-vision-489669.html

The Times blogosphere: http://blogs.thetimes.co.za/

\section{About the author}

Mpumelelo Mkhabela is a South African news reporter. 